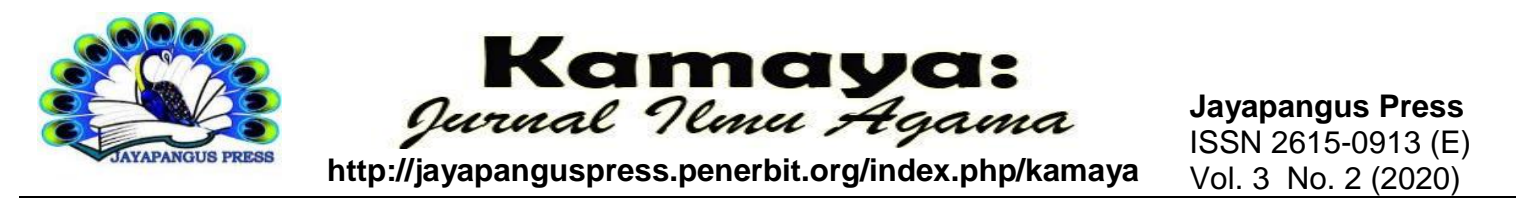

\title{
Tindak Pidana Kekerasan Seksual Terhadap Anak Menurut Hukum Hindu
}

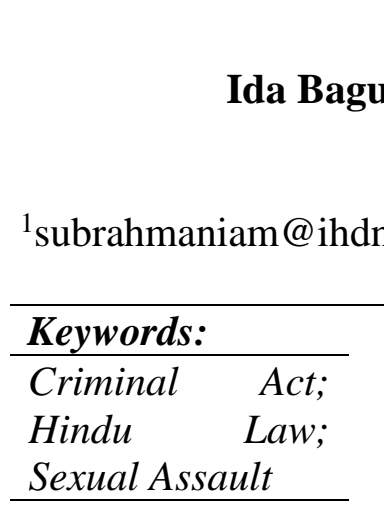

Oleh :

I Komang Suastika Arimbawa
${ }_{1,2,3}$
Institut Hindu Dharma Negeri Denpasar

n.ac.id, ${ }^{2}$ paseksubawa@ihdn.ac.id, ${ }^{3}$ suastikaarimbawa@ihdn.ac.id 
melanggarnya. Salah satu perbuatan yang dewasa ini sering terjadi di masyarakat adalah eksploitasi anak. Salah satu kasus ekploitasi anak yang terjadi seperti kasus pelecehan seksual terhadap anak. Faktor penyebabnya yaitu, faktor internal (seperti kedekatan pelaku dengan korban) dan faktor eksternal (seperti jauh dari keramaian). Karena hal itulah, upaya perlindungan anak sangat perlu dilakukan. Menurut Undang-Undang Nomor 23 Tahun 2002, seorang anak diberi perlindungan sejak dalam kandungan hingga berumur 18 (delapan belas) tahun. Berkenaan dengan hal itu, dalam Hindu juga dapat dijumpai istilah hukum yang dikenal sebagai dharma. Hukum Hindu dibedakan menjadi dua, yaitu hukum publik (Kantaka Sodhāna atau hukum pidana Hindu) dan hukum privat (Dharmasthiya atau hukum perdata Hindu). Kantaka Sodhāna dapat dipandang dalam arti subyektif (ius puniedi) dan dalam arti obyektif (ius poenale). Kemudian, mengenai tindak pidana kekerasan seksual terhadap anak tidak diatur secara khusus dalam hukum Hindu, namun hubungan yang dilakukan antara laki-laki dengan perempuan yang tidak memiliki ikatan pawiwahan (perkawinan) yang sah, maka perbuatan ini merupakan suatu tindak pidana yang disebut lokika sanggraha. Oleh karena itu, tindakan kekerasan seksual terhadap anak dapat disamakan dengan perbuatan lokika sanggraha. Berkaitan dengan hal ini, dalam Pasal 171 Ekadaso'dhyayah Mānava Dharmaśāstra, perbuatan tersebut dapat disalahkan dan diancam tapa selama 12 (dua belas) tahun. Istilah tapa harus diartikan penjara karena dalam keadaan seseorang dipenjara sama menderita sebagai seorang pertapa.

\section{Pendahuluan}

Negara Kesatuan Republik Indonesia yang berdasarkan atas Pancasila yang selanjutnya dijabarkan secara lengkap di dalam Undang-Undang Dasar Negara Republik Indonesia Tahun 1945 mengatur tingkah laku warga Negara Indonesia tidak terlepas dari peraturan hukum yang berlaku. Dalam Pasal 1 ayat (3) UUD Negara Republik Indonesia Tahun 1945 menyatakan “Negara Indonesia adalah Negara hukum”. Hal ini menghendaki hukum selalu ditegakkan, dihormati, dan ditaati, oleh siapapun juga tanpa terkecuali. Ini bertujuan agar menciptakan keamanan dan ketertiban dalam kehidupan bermasyarakat dan bernegara.

Dalam menciptakan keamanan dan ketertiban dalam kehidupan masyarakat maka dibuatlah suatu hukum yang mengayomi seluruh lapisan masyarakat. Meskipun hukum dibuat untuk menertibkan masyarakat tetap saja ada yang melanggar hukum tersebut. Akibat yang ditimbulkan oleh pelanggar hukum tentunya akan dikenakan sanksi hukum sesuai dengan perbuatan yang dilanggarnya. 
Salah satu perbuatan yang dewasa ini sering dijumpai adalah eksploitasi anak, seperti kasus pelecehan seksual terhadap anak dalam lingkungan keluarga maupun masyarakat. Pelaku biasanya adalah kerabat terdekat dari korban. Kekerasan seksual terhadap anak termasuk dalam pengertian kejahatan kesusilaan yang harus ditangani secara serius dan konsisten. Hal ini dikarenakan anak adalah amanah sekaligus karunia Tuhan Yang Maha Esa, yang senantiasa harus kita jaga karena dalam dirinya melekat harkat, martabat, dan hak-hak sebagai manusia yang harus dijunjung tinggi. Dari sisi kehidupan berbangsa dan bernegara, anak adalah masa depan bangsa dan generasi penerus bangsa, sehingga setiap anak berhak atas kelangsungan hidup, tumbuh, dan berkembang, berpartisipasi, serta berhak atas perlindungan dari tindak kekerasan dan diskriminasi (Amijaya, 2006).

Faktor-faktor penyebab terjadinya tindak pidana kekerasan seksual ada 2, yaitu faktor internal dan faktor eksternal. Faktor internal seperti kedekatan pelaku dengan korban, peran pelaku, dan posisi korban. Faktor eksternal, yaitu pengaruh lingkungan, seperti jauh dari keramaian, sepi, ataupun tempat tertutup yang memungkinkan pelaku melakukan kekerasan seksual (Saitya, 2019).

Undang-Undang Nomor 23 Tahun 2002 Tentang Perlindungan Anak, menegaskan anak adalah amanah sekaligus karunia Tuhan Yang Maha Esa, yang senantiasa harus kita jaga karena dalam dirinya melekat harkat, martabat, dan hak-hak sebagai manusia yang harus dijunjung tinggi. Undang-Undang Nomor 39 Tahun 1999 Tentang Hak Asasi Manusia menyebutkan dalam Pasal 52 tentang hak anak, pelaksanaan dan tanggung jawab orang tua, keluarga, masyarakat, pemerintah, dan negara terhadap anak dengan jalan memberi perlindungan terhadap anak, namun masih diperlukan undang-undang yang khusus mengenai perlindungan anak. Undang-Undang perlindungan anak diperlukan sebagai landasan yuridis bagi pelaksanaan kewajiban dan tanggung jawab terhadap anak.

Upaya perlindungan anak perlu dilaksanakan sedini mungkin, menurut UndangUndang Nomor 23 Tahun 2002 Tentang Perlindungan Anak sejak dalam kandungan hingga berumur 18 (delapan belas) tahun seorang anak diberi perlindungan. Perlindungan anak adalah suatu usaha untuk melindungi anak agar dapat melaksanakan hak dan kewajibannya secara seimbang dan manusiawi.

Anak-anak korban kejahatan merupakan manusia golongan lemah yang sering kali tidak bisa melindungi dan membantu dirinya sendiri karena situasi dan kondisinya. 
Perlindungan khusus bagi anak korban kekerasan yang diatur dalam Pasal 69 UndangUndang Nomor 23 Tahun 2002 Tentang Perlindungan anak meliputi kekerasan fisik, psikis, dan seksual, yaitu dengan cara mensosialisasikan ketentuan peraturan perundangundangan yang melindungi anak korban kejahatan.Oleh karena itu, setiap orang dalam kondisi apapun harus dilindungi kebebasannya, khususnya untuk anak yang masih di dalam kandungan hingga berusia 18 (delapan belas) tahun.

\section{Metode}

Tindak pidana kekerasan seksual terhadap anak menurut hukum Hindu menggunakan metode penelitian kualitatif. Menurut Moleong (2014), penelitian kualitatif adalah penelitian yang bermaksud untuk memahami fenomena tentang apa yang dialami oleh subjek penelitian misalnya perilaku, persepsi, motivasi, tindakan, secara holistik, dan dengan cara deskripsi dalam bentuk kata-kata dan bahasa, pada suatu konteks khusus yang alamiah dan dengan memanfaatkan berbagai metode alamiah.

Teknik pengumpulan data yang digunakan, yaitu studi dokumen dan studi kepustakaan. Studi kepustakaan mencari sumber-sumber untuk penulusuran teks-teks, naskah-naskah, buku-buku yang berkaitan dengan penelitian yang diteliti dari berbagai tempat. Menurut Moleong (2014) dokumen sudah lama digunakan dalam penelitian sebagai sumber data karena dalam banyak hal dokumen sebagai sumber data dimanfaatkan untuk menguji, menafsirkan, bahkan untuk meramalkan. Teknik analisis data yang digunakan berupak reduksi data, klasifikasi data, display data, dan penarikan kesimpulan.

\section{Pembahasan}

Dalam Veda dapat dijumpai istilah hukum, yaitu sebagai hukum abadi yang disebut rta dan hukum duniawi disebut dharma. Kata dharma berasal dari bahasa sanskerta, yang berarti hukum, kebiasaan, kealiman, kebajikan, aturan, kebenaran, tugas, keadilan, jasa, karakter, suatu keanehan, jiwa, dewa kematian, anak sulung dari Pandawa. Dalam hal ini, dharma diartikan sebagai hukum. Dharma dapat disebut hukum, apabila norma-normanya memuat unsur-unsur yang sifatnya mengatur atau unsur-unsur sifatnya memaksa. Dharma merupakan hukum yang mengatur dan memelihara hubungan serasi antara manusia dengan penciptanya dan dengan ciptaan Tuhan yang lainnya. 
Menurut Ekasana (2012), hukum Hindu menurut Kautilya dibagi menjadi 2 (dua) bidang, yaitu hukum publik disebut Kantaka Sodhāna dan hukum privat disebut Dharmasthiya. Kantaka Sodhāna di Indonesia dikenal dengan hukum pidana Hindu, sedangkan Dharmasthiya di Indonesia dikenal dengan hukum perdata Hindu. Kantaka Sodhāna adalah hukum yang hidup, diikuti, dan ditaati oleh masyarakat Hindu. Ditinjau dari Pasal 6 Dvityo 'dhyayah Mānava Dharmśāstra, dari sudut acaranya apabila ada yang melanggarkebiasaan-kebiasaan yang sedang berlaku dalam masyarakat Hindu maka pelanggarnya dikenakan sanksi pidana.

Kantaka Sodhāna dapat dipandang dalam arti subyektif dan dalam arti obyektif. Kantaka Sodhāna dalam arti subyektif disebut juga ius puniedi, yaitu sejumlah peraturanperaturan yang mengatur hak negara untuk menghukum seseorang yang melakukan perbuatan terlarang (Ekasana, 2012). Kantaka Sodhāna dalam arti subyektif dapat dilihat dalam Pasal 306 Astamo’dhyayah Mānava Dharmaśāstra sebagai berikut.

rakșan dharmeña bhütāni

rājā vadhyāimś ca ghātayan, yajate 'hararharyajñaih

sahasra śata dakșinaiḥ.

Terjemahannya :

Raja yang melindungi segala makhluk sesuai menurut hukumnya dan menghukum mereka yang patut dihukum, sebagai perbuatan yajña yang setiap harinya ratusan ribu dipersembahkan sebagai bayaran (Pudja dan Sudharta, 2004:306).

Kantaka Sodhāna dalam arti obyektif disebut juga ius poenale, yaitu sejumlah peraturan-peraturan yang berisikan larangan-larangan dan keharusan-keharusan, yang mana pelanggarnya dapat diancam dengan suatu hukuman. Kantaka Sodhāna dalam arti obyektif dibagi menjadi 2, yaitu Kantaka Sodhāna material dan Kantaka Sodhāna formal (Ekasana, 2012:4).

Menurut Ekasana (2012) Kantaka Sodhāna material adalah peraturan-peraturan yang berisikan ketentuan-ketentuan mengenai :

a. Perbuatan yang dapat diancam dengan suatu hukuman, contoh pencurian, perbuatan zina (paradara), pembunuhan atau kejahatan terhadap nyawa.

b. Subyek hukum yang dapat disalahkan melakukan perbuatan hukum tertentu.

c. Hukuman yang dijatuhkan kepada seseorang yang melakukan kejahatan, antara lain tapa (penjara), prayascitta (memulihkan kembali kondisi 
lingkungan yang tercemar akibat tindak pidana yang dilakukan), wrata atau danda, semuanya itu tergantung akibat hukum yang ditimbulkan dari suatu kejahatan.

Kantaka Sodhāna formal adalah sejumlah peraturan-peraturan yang berisikan cara-cara negara menggunakan hak-haknya untuk melaksanakan hukuman. Dengan kata lain, Kantaka Sodhāna dormal adalah sejumlah peraturan-peraturan yang berisikan caracara menerapkan Kantaka Sodhāna, sehingga disebut sebagai Kantaka Sodhāna Acara (hukum acara pidana Hindu) (Ekasana, 2012).

Ada beberapa tindak pidana yang diatur dalam Kantaka Sodhāna, yaitu dusta (kejahatan terhadap nyawa), corah (kejahatan terhadap harta benda), paradara (kejahatan terhadap kesusilaan), duwilatek (fitnah), samwidwayatikarma atau kagelehan (hukum mengenai tidak melakukan tugas yang dijanjikan atau kelalaian), wakparusya (penghinaan), dan dyutāmahwaya (perjudian). Dalam hal ini akan lebih mengkhusus kepada tindak pidana paradara.

Tindak pidana kekerasan seksual terhadap anak tidak diatur secara khusus dalam hukum Hindu, namun hubungan yang dilakukan antara laki-laki dengan perempuan yang tidak memiliki ikatan pawiwahan (perkawinan) yang sah, maka perbuatan ini merupakan suatu tindak pidana yang disebut lokika sanggraha. Oleh karena itu, tindakan kekerasan seksual terhadap anak dapat disamakan dengan perbuatan lokika sanggaraha. Lokika sanggraha dipandang sebagai suatu hubungan kelamin yang dilakukan atas suka sama suka antara laki-laki dengan perempuan tanpa ikatan perkawinan.

Secara etimologi istilah lokika sanggraha berasal dari bahasa Sanskerta terdiri dari 2 (dua) kata, yaitu laukika dan sanggra. Laukika berarti orang umum, orang banyak, sedangkan sanggra artinya pegang (dalam arti luas), sentuh, hubungan. Jadi, lokika sanggraha berarti dipegang/disentuh/dijamah orang (Ekasana, 2012).

Lokika sanggraha merupakan salah satu delik adat menyangkut kesusilaan yang oleh masyarakat Bali keberadaannya diakui sejak zaman kerajaan dahulu hingga sekarang. Delik ini adalah suatu perbuatan yang sangat bertentangan dengan norma hukum adat, karena dapat mengganggu keseimbangan dan keselamatan di lingkungan kesatuan masyarakat hukum adat. Adapun unsur-unsur dari lokika sanggraha, antara lain:

a. Adanya hubungan cinta antara laki-laki dengan perempuan yang sama-sama belum terikan perkawinan. 
b. Antara laki-laki dengan perempuan yang sedang bercinta terjadi hubungan seksual yang didasarkan atas suka sama suka.

c. Laki-laki berjanji akan mengawini perempuan.

d. Hubungan seksual yang telah dilakukan menyebabkan perempuan menjadi hamil.

e. Laki-laki ingkar mengingkarijanjinya untuk mengawini perempuan tanpa alasan (Widnyana dalam Ekasana, 2012).

Di dalam Pasal 171 dan 177 Ekadaso 'dhyayah Mānava Dharmaśāstra juga diatur mengenai lokika sanggraha, yaitu:

\section{guru talpa vrataim kuryād retah siktvā svayonișu, sukhyuh putrasya ca strīṣu kumārì șvantyajāsu ca.}

(Mānava Dharmaśāstra XI.171)

Terjemahannya:

Ia yang telah melakukan hubungan kelamin dengan wanita saudara kandungnya, dengan istri teman atau dengan istri anak, dengan wanita belum kawin dan dengan wanita golongan rendah harus melakukan tapa sebagaimana yang harus dilakukan karena melanggar tempat tidur (Pudja dan Sudharta, 2004:588).

vipra duștāim striyam bhartțā

nirundhyādeka veśmani,

yat pumsah paradāreșu

tac cainām cārayed vratam.

Terjemahannya:

(Mānava Dharmaśāstra XI.177)

Istri yang sangat korup hendaknya supaya suaminya memencilkannya pada sebuah ruangan dan memaksanya untuk melakukan tapa yang diwajibkan bagi seorang laki-laki dalam hal perzinaan (Pudja dan Sudharta, 2004).

Penjelasan Pasal 171 Ekadaso'dhyayah Mānava Dharmaśāstra, perbuatan tersebut dapat disalahkan dan diancam tapa selama 12 (dua belas) tahun. Istilah tapa harus diartikan penjara karena dalam keadaan seseorang dipenjara sama menderita sebagai seorang pertapa. Penjelasan Pasal 177 Ekadaso 'dhyayah Mānava Dharmaśāstra, berzina tergolong jenis upapataka, yang dapat disucikan dengan tapa candrayana (sanksi hukum selama jumlah bulan yang ditentukan). Istri yang sangat korup misalnya yang berbuat zina. Menurut beberapa penafsiran, besar kecilnya tapa atas zina didasarkan atas jenis, golongan, atau lainnya yang dapat mempengaruhi pertimbangan terhadap ancaman tersebut (Ekasana, 2012). 
Tindak pidana perkosaan adalah hubungan antara laki-laki dengan perempuan layaknya suami istri dan terdapat unsur kekerasan. Norma hukum Hindu yang berkaitan dengan perkosaan diuraikan dalam Pasal 364 Astamo'dhyayah Mānava Dharmaśāstra sebagai berikut.

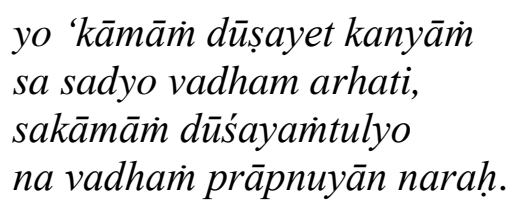

(Mānava Dharmaśāstra VIII.364)

Terjemahannya:

Ia yang memperkosa wanita yang tidak mau, dihukum jasmani langsung, tetapi seseorang yang menikmati dengan kemauan wanita itu, tidak diancam hukuman jasmani bila dilakukan dengan wanita segolongan (Pudja dan Sudharta, 2004:425).

Dari uraian Pasal di atas, apabila laki-laki memperkosa perempuan maka akan langsung dikenakan hukuman jasmani. Apabila dalam kondisi saat ini sulit tampaknya untuk dihukum secara langsung, tindak pidana ini harus dibuktikan terlebih dahulu barulah dapat dikenakan hukuman. Tindak pidana kekerasan seksual terhadap anak memang belum secara khusus diatur dalam hukum hindu, namun seperti uraian di atas mengenai lokika sanggraha dan perkosaan nampaknya sedikit menjawab mengenai kekerasan seksual terhadap anak meskipun hukumannya dirasa kurang adil.

\section{Kesimpulan}

Pengaturan sanksi pidana dalam tindak pidana kekerasan seksual terhadap anak dalam hukum Hindu memang belum diatur, namun tindak pidana ini dapat disamakan dengan perbuatan lokika sanggraha. Perbuatan lokika sanggraha dapat disebut perbuatan zina yang diatur dalam Mānava Dharmaśāstra, di samping perbuatan zina, perbuatan perkosaan juga diatur dalam kitab tersebut. Peraturan yang mengatur tentang perlindungan anak, baik dalam hukum nasional maupun dalam hukum Hindu sebaiknya dilaksanakan secara sungguh-sungguh demi memberikan perlindungan serta menjaga harkat dan martabat anak sebagai generasi penerus bangsa dari segala bentuk kekerasan seksual yang terjadi di dalam masyarakat sehingga masyarakat takut melakukan tindak pidana atau menjadi pelaku tindak pidana. 


\section{Daftar Pustaka}

Amijaya, M. T. (2006). Penerapan Hukum Pasa Kasus Kekerasan Seksual Terhadap Anak Setelah Berlakunya UU RI No. 23 Tahun 2002 Tentang Perlindungan Anak. Universitas Warmadewa.

Ekasana, I. M. S. (2012). Hukum Pidana Hindu Kantaka Sodhāna. Denpasar: Institut Hindu Dharma Negeri.

Moleong, L. J. (2014). Metodologi Penelitian Kualitatif Edisi Revisi. Bandung: PT. Remaja Rosdakarya Offset.

Pudja, G. dan T. R. S. (2004). Mānava Dharmaśāstra (Manu Dharmaśāstra) atau Veda Smrti Compendium Hukum Hindu. Surabaya: Pāramita.

Saitya, I. B. S. (2019). Faktor-faktor penyebab tindak pidana kekerasan seksual terhadap anak. Vyavahara Duta, XIV(1), 1-7.

Undang-Undang Negara Republik Indonesia Nomor 23 Tahun 2002 Tentang Perlindungan Anak.Lembaran Negara Republik Indonesia Tahun 2002 Nomor 109.Tambahan Lembaran Negara Republik Indonesia Nomor 4235. 